\title{
Identification and purification of EBP1: a HeLa cell protein that binds to a region overlapping the 'core' of the SV40 enhancer
}

\author{
Lilian Clark, Roy M. Pollock, ${ }^{1}$ and Ronald T. Hay ${ }^{2}$ \\ Department of Biochemistry and Microbiology, University of St. Andrews, Fife, KY16 9AL, Scotland
}

\begin{abstract}
The SV40 enhancer consists of multiple DNA sequence motifs that are recognized by a variety of trans-acting factors. Using DNase I protection and a gel electrophoresis DNA-binding assay, we identified a HeLa cell protein (EBP1) that binds to the 'core' region of the SV40 enhancer. A short double-stranded synthetic oligonucleotide containing the binding site for EBP1 was used to assay for EBP1 activity and to purify a 57,000m.w. polypeptide by recognition site affinity chromatography. Bromodeoxyuracil cross-linking identified a $60,000-\mathrm{m} . w$. species as the polypeptide responsible for the DNA-binding activity. Analysis of the DNA sequences required for EBP1 binding indicated that EBP1 could be distinguished from a number of recently characterized proteins (EBP20, AP-2, and AP-3) by its binding to a variety of mutant templates. Correlation of the in vivo transcriptional activity of wild-type and mutated enhancers with EBP1 binding indicates that this protein may be important for SV40 enhancer activity because mutations that abolish EBP1 binding also have a severe deleterious effect on transcription.
\end{abstract}

[Key Words: SV40 enhancer; DNA-binding protein; transcription factor; affinity chromatography]

Received March 7, 1988; revised version accepted June 10, 1988.

Transcriptional control in eukaryotes has been shown to be modulated by the interaction of sequence-specific DNA-binding proteins with their cis-acting recognition sites (for review, see Jones et al. 1988). These target DNA sequences can be located close to the $5^{\prime}$ end of a gene as part of the conventionally defined promoter. If the target sites are part of an enhancer, considerably more flexibility is exhibited in the positioning of control sequences: The hallmark of enhancer sequences is that they can activate transcription of linked genes in a position- and orientation-independent manner with respect to the responding promoter. Although some enhancers are active in a variety of cell types, an increasing number have been identified that are functional only in specific cell types. The immunoglobulin heavy-chain and insulin gene enhancers are examples in this category (Banerii et al. 1983; Gillies et al. 1983; Ohlsson and Edlund 1986). Another class of enhancers, exemplified by those present in the mouse mammary tumor virus long terminal repeat (MMTV LTR; Chandler et al. 1983), c-fos gene (Treisman 1985), and human $\beta$-interferon gene (Goodbourn et al. 1985), are only active in response to an appropriate inducer.

\footnotetext{
'Present address: Imperial Cancer Research Fund, Lincoln's Inn Fields, London, WC2A 3PX, England.

${ }^{2}$ Corresponding author.
}

al. 1981; Moreau et al. 1981) is regarded as the prototype enhancer. Although it is active in a number of cell types, it also demonstrates distinct cell-type specificities (Schirm et al. 1987), and its activity is stimulated in cells treated with phorbol esters (Chiu et al. 1987). The flexible response of the SV40 enhancer appears to result from its modular construction in which multiple sequence motifs act in concert to generate enhancer activity (Herr and Clark 1986; Zenke et al. 1986). Each of these sequence motifs represents the binding site for at least one trans-acting factor (Wildeman et al. 1986), and it appears to be the interaction of the trans-acting factors with the transcriptional machinery that is responsible for enhancer function. These sequence motifs display cell-type specificities in vivo (Nomiyama et al. 1987; Ondek et al. 1987) and bind proteins in vitro that are cell-type specific (Davidson et al. 1986; Xiao et al. 1987a). The multiplicity of protein-binding sites within the SV40 enhancer creates a situation in which gene expression can be controlled by the binding of different combinations of interacting transcription factors. In this respect, it has also been demonstrated that cellular proteins can bind to overlapping motifs within the SV40 enhancer (Xiao et al. 1987b), thus giving rise to the possibility that transcriptional activity may not only be modulated by the binding of a particular factor but also by the ability of the bound factor to exclude binding of 
other antagonistically acting factors. An example of this type is provided by the inducible enhancer element of the human $\beta$-interferon gene. It is thought that in the uninduced state, a repressor bound to the enhancer excludes the binding of a positive transcription factor. After induction, the positive transcription factor gains access to its recognition site in the enhancer and stimulates transcription (Goodbourn et al. 1986; Zinn and Maniatis 1986).

Purification of transcription factors that interact with the SV40 enhancer has defined a number of proteins with interesting properties. Transcription factor AP-1 interacts with phorbol-ester-inducible elements within the SV40 enhancer (Angel et al. 1987; Lee et al. 1987) and stimulates transcription in a reconstituted in vitro system (Lee et al. 1987). Likewise, the transcription factor AP-2 binds to different phorbol-ester-responsive elements in the SV40 enhancer and activates transcription in vitro (Imagawa et al. 1987; Mitchell et al. 1987). Two proteins, EBP20 (Johnson et al. 1987) and AP-3 (Mitchell et al. 1987), have been shown to bind in the 'core' region of the SV40 enhancer, which mutational studies indicate is important for enhancer function (Laimins et al. 1982; Weiher et al. 1983; Zenke et al. 1986). Here, we describe the purification, from HeLa cells, of a protein that binds to this region of the SV40 enhancer but is distinct from the previously described EBP20 (Johnson et al. 1987) or AP-2 and AP-3 (Mitchell et al. 1987). Mutations in the recognition site of this protein, EBP1, which abolish binding, have been shown previously to have a severe deleterious effect on enhancer-mediated transcription (Zenke et al. 1986; Nomiyama et al. 1987; Ondek et al. 1987).

\section{Results \\ Detection of cellular proteins that interact with the SV40 enhancer}

The SV40 enhancer consists of the two 72-bp repeats and additional DNA sequences that extend to the PvuII site (Fig. 1A). In our studies, a plasmid (pUC1X72), derived from pMKD 231 (Everett et al. 1983), with a single 72-bp element, has been used as a source of DNA containing SV40 enhancer sequences. Cellular proteins that bind specifically to the SV40 enhancer were detected by a gel electrophoresis DNA-binding assay (Fried and Crothers 1981; Garner and Revzin 1981). A 173-bp ${ }^{32}$ P-labeled $B a m H I-E c o R I$ fragment derived from pUC1X72 was incubated with a nuclear extract from HeLa cells that had been partially purified by DEAE-Sepharose chromatography. Interactions between nonspecific DNA-binding proteins and the labeled probe were minimized by the inclusion, in the binding reaction, of a large excess of an equimolar mixture of poly[d(G-C)] and poly[d(A-T)]. Native polyacrylamide gel electrophoresis of the binding reactions resolved free DNA from three distinct DNAprotein complexes labeled $a, b$, and $c$ in Figure 1B. To determine the sequence specificity of the proteins responsible for the formation of the different DNA-protein complexes, double-stranded oligonucleotides that spanned a number of the motifs recognized in the SV40 enhancer were synthesized. SV1 contains the GT-I and part of the TC-II motifs, whereas SV2 contains the GT-II motif and SV3 the Sph-I, Sph-II, octamer, and part of the $P$ motif (for nomenclature, see Xiao et al. 1987a, for review, see Jones et al. 1988). Competition analysis, in which an excess of the unlabeled double-stranded oligonucleotide is included in the binding reaction, indicated that the formation of complex a was diminished in the presence of SV1 and, to a lesser extent, by SV2, whereas formation of complex $b$ was unaffected by the presence of SV1, SV2, or SV3 (Fig. 1B). Formation of complex $c$ was abolished by inclusion of the SV1 double-stranded synthetic oligonucleotide in the binding reaction but was unaffected by the inclusion of the SV2 and SV3 double-stranded synthetic oligonucleotides. The origin of complex $\mathrm{c}$ was investigated further by repeating these experiments with a shorter ${ }^{32} \mathrm{P}-\mathrm{la}$ beled DNA fragment of $97 \mathrm{bp}$, which extends from the BamHI to the PvuII site. Only one DNA-protein complex was resolved by polyacrylamide gel electrophoresis after incubation of the labeled probe with the nuclear extract (Fig. 1C). Equivalence of this single DNA-protein complex with complex c observed previously was suggested by a similar electrophoretic mobility and by the fact that formation of the complex was competed for by inclusion of the double-stranded SV1 oligonucleotide (Fig. 1C).

\section{DNase protection analysis of nuclear proteins binding to the SV4O enhancer}

To identify the binding sites of the nuclear proteins on the SV40 genome, DNase I protection experiments (Galas and Schmitz 1978) were carried out. Using a ${ }^{32} \mathrm{P}-$ labeled EcoRI-BamHI fragment as probe, two areas of the SV40 enhancer were protected from DNase I digestion in the presence of HeLa cell nuclear protein (Fig. 2). The area from position 233 to 252 contains the GT-I motif, whereas the region from 262 to 290 contains the GT-II motif. The addition of an excess of the unlabeled SV1 double-stranded synthetic oligonucleotide to the binding reaction abolished protection between positions 233 and 252 but had no effect in the region from 262 to 290. Conversely, addition of an excess of unlabeled SV2 double-stranded synthetic oligonucleotide reduced the protection over the GT-II motif, whereas the footprint over the GT-I motif was unaltered. The pattern of DNase I protection was not altered substantially in the presence of excess SV3 double-stranded synthetic oligonucleotide (Fig. 2). To investigate the requirements for sequence-specific binding in the GT-I region, competition assays in which double-stranded oligonucleotides corresponding to SV1 with specific base pair alterations were included in the binding reactions as above. Alteration of the two Gs at positions 244 and 245 to Cs (SV1.M1) abolished the ability of the double-stranded oligonucleotide to compete for binding of the nuclear factors, whereas changing A241 to T (SV1.M2) did not alter the ability of the double-stranded oligonucleotide to compete for binding of the nuclear factors (Fig. 2). 
Purification of a cellular protein that binds to the SV4O enhancer

The factor that binds to the GT-I motif in the SV40 enhancer could also bind to the SV1 double-stranded synthetic oligonucleotide (Figs. 1 and 2). Thus, as a means of following purification of the GT-I binding fraction, we used ${ }^{32}$ P-labeled SV1 double-stranded oligonucleotide as probe in the gel electrophoresis DNA-binding assay (Fig.
3). HeLa cells ( $40 \mathrm{~g}$ wet weight) were fractionated into nuclei and cytosol, and the nuclei extracted with $0.35 \mathrm{M}$ $\mathrm{NaCl}$. The nuclear extract, which contained the bulk of the binding activity, was freed of nucleic acids by passage over DEAE-Sepharose and, after reduction of the $\mathrm{NaCl}$ concentration was applied to a second DEAESepharose column. Bound proteins were eluted with a linear gradient from 0.05 to $0.4 \mathrm{M} \mathrm{NaCl}$, and individual fractions were monitored for DNA-binding activity.

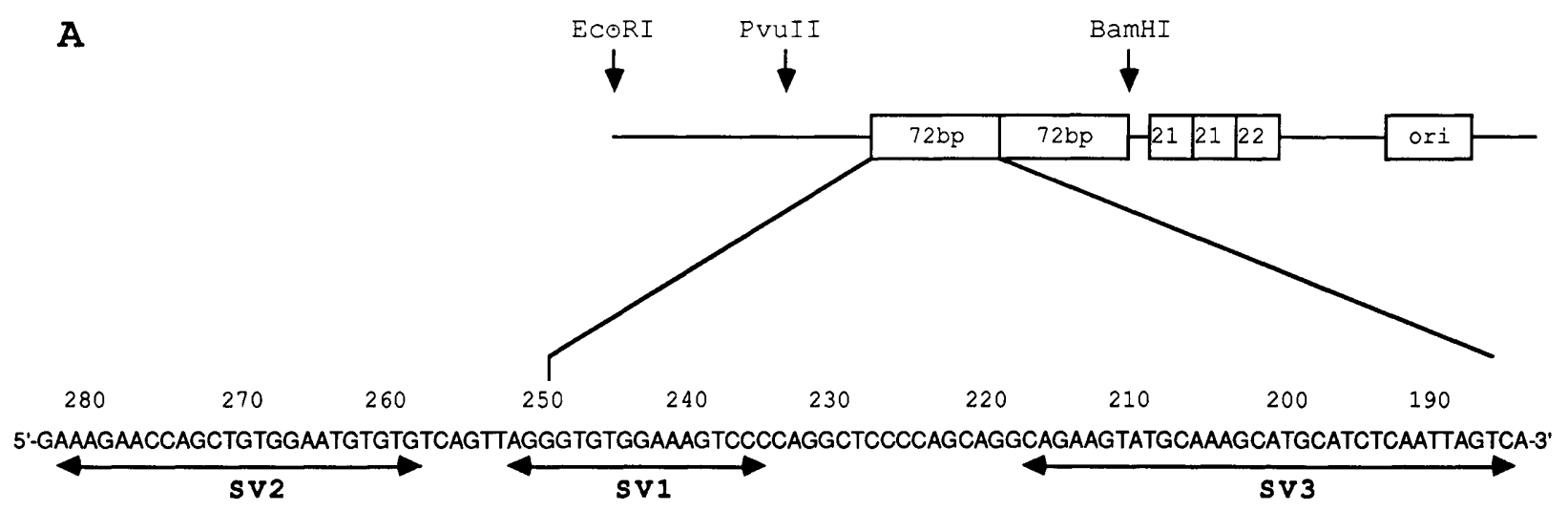

B

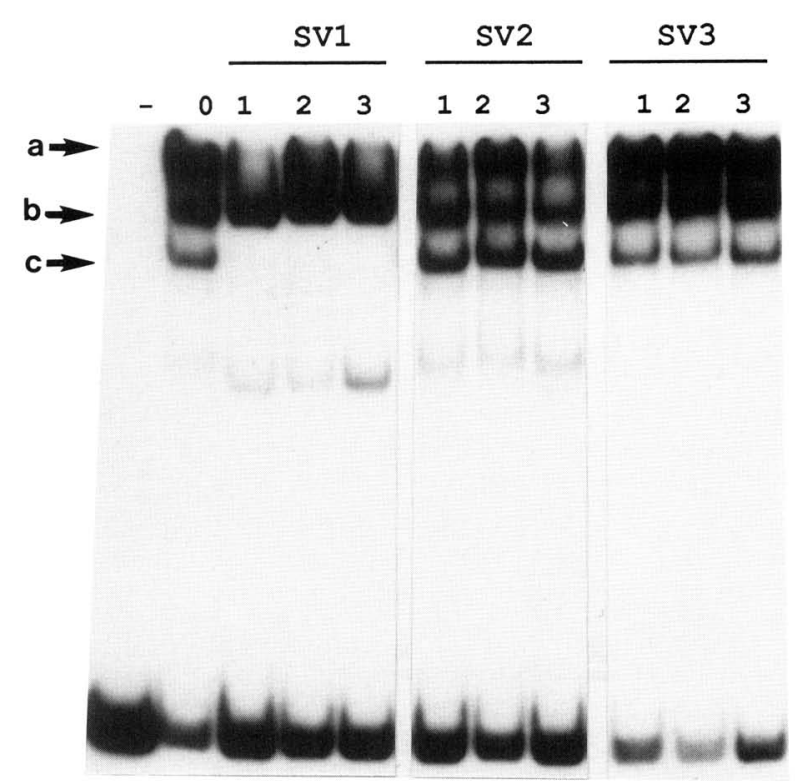

Eco RI-Bam HI

C

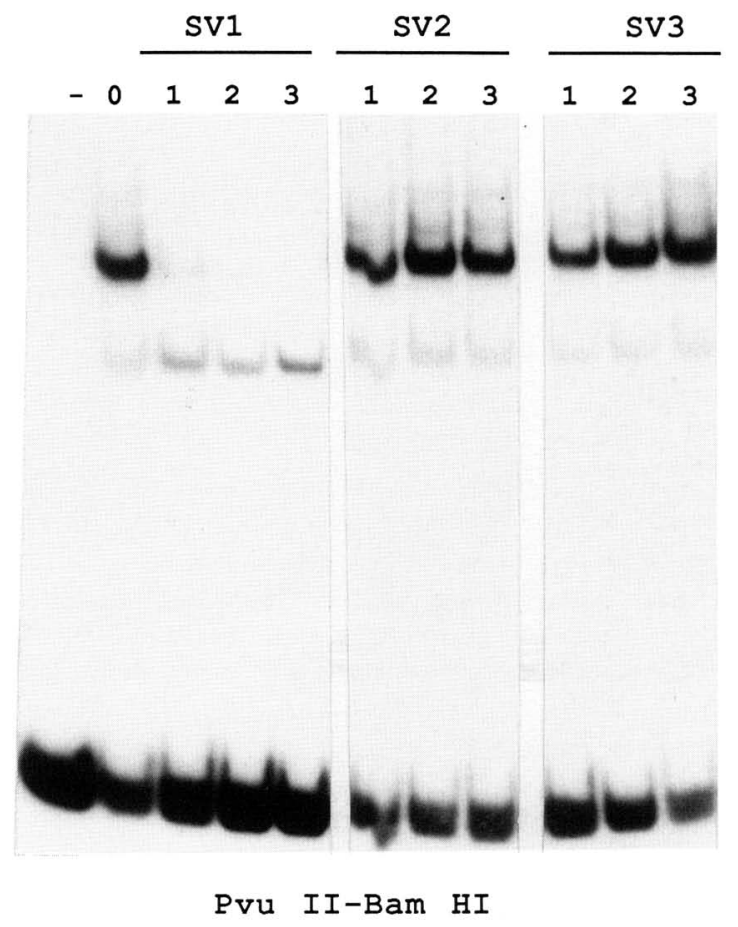

Figure 1. Detection of enhancer-binding proteins in HeLa cell nuclear extracts. $(A)$ Organization of the SV40 transcriptional control region. Relevant restriction enzyme cleavage sites and important elements of the promoter and enhancer present in plasmid pMKD 231 are indicated. Shown below is the DNA sequence of the enhancer region. DNA sequences present in the double-stranded synthetic oligonucleotides SV1, SV2, and SV3 are also indicated. Probes labeled with ${ }^{32} \mathrm{P}$ containing the 72 -bp enhancer element, EcoRIBamHI- $(B)$ or PvuII-BamHI- $(C)$ digested pUC1X72, were incubated with $2 \mu \mathrm{g}$ nuclear extract (partially purified over DEAE-Sepharose) in the standard gel electrophoresis DNA-binding assay, as described in Materials and methods (lanes - contained no nuclear extract). Also included in the reaction mixture was 25 (lanes 1), 50 (lanes 2), or 100 (lanes 3) ng of unlabeled double-stranded synthetic oligonucleotides SV1, SV2, or SV3. 


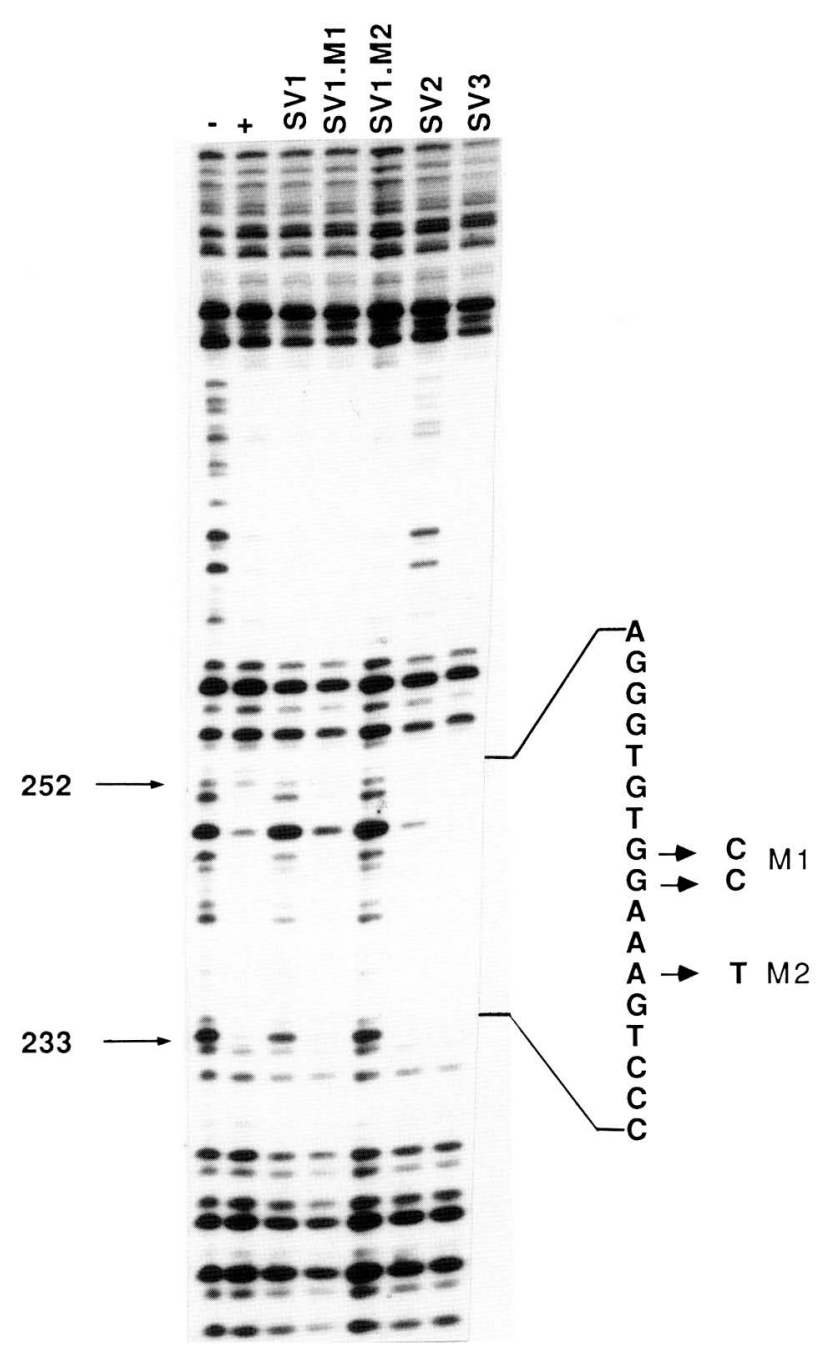

Figure 2. DNase I protection of the SV40 enhancer by partially purified enhancer-binding factors. A BamHI-EcoRI fragment from pUClX72, 5'-end labeled at the BamHI site, was incubated with $40 \mu \mathrm{g}$ of nuclear extract (DEAE-Sepharose fraction) and digested with DNase $I$, as described in Materials and methods (lane - contained no nuclear extract). Included in the reaction mixture was $100 \mathrm{ng}$ of unlabeled double-stranded oligonucleotides, SV1, SV1.M1, SV1.M2, SV2, or SV3. After treatment with DNase I, reaction products were electrophoresed in a $6 \%$ denaturing polyacrylamide gel, and the cleavage products visualized by autoradiography. Oligonucleotides SV1.M1 and SV1.M2 are derivatives of SV1 in which cytosines 244 and 245 have been altered to guanines (SV1.M1) and thymine 241 has been altered to adenine (SV1.M2).
Using this procedure, it was possible to resolve two distinct species that bound to the SV1 double-stranded oligonucleotide (Fig. 3). The two species appear to have identical sequence specificities, and bromodeoxyuracil cross-linking experiments indicate that the cross-linked polypeptide is of identical molecular weight in each case (data not shown). Fractions containing the two binding species were pooled and purified further by recognition site affinity chromatography (Kadonaga and Tjian 1986; Rosenfeld and Kelly 1986). The pooled DEAE-Sepharose fractions were mixed with poly $[\mathrm{d}(\mathrm{A}-\mathrm{T})]$ and poly $[\mathrm{d} / \mathrm{G}$ C)l, as nonspecific competitor DNAs, and applied to a DNA affinity resin composed of tandemly ligated SVl double-stranded oligonucleotide coupled to cyanogenbromide-activated Sepharose-4B (Pharmacia). Whereas the bulk of the proteins in the DEAE fractions flow through the affinity column, the SV1-binding activity was specifically retained on the column and could be eluted by raising the $\mathrm{NaCl}$ concentration to $1.0 \mathrm{M}$ (Fig. 4A). Two further rounds of affinity chromatography resulted in a preparation in which the specific binding activity had increased by 15,000 -fold when compared to the crude nuclear extract (Table 1). Samples from various steps in the purification procedure were precipitated with trichloroacetic acid (TCA) and analyzed by SDS-polyacrylamide gel electrophoresis followed by silver staining. The third-round affinity fraction contained predominantly a $57,000-\mathrm{m} . \mathrm{w}$. polypeptide (Fig. 4B). From 40 grams of HeLa cells we obtained $8 \mu \mathrm{g}$ of purified protein with $13.4 \%$ recovery of specific DNAbinding activity (Table 1). Because the purified protein bound to the SVI region of the SV40 enhancer, we have designated this protein EBP1.

Identification of the 57,000-m.w. polypeptide (EBP1) as the specific DNA-binding species

To determine that the 57,000-m.w. polypeptide (EBP1) contained the activity responsible for binding to the SVI oligonucleotide, we cross-linked bound protein to bromodeoxyuracil-substituted, ${ }^{32} \mathrm{P}$-labeled DNA (Ogata and Gilbert 1977). The double-stranded SV1 oligonucleotide was first inserted into $\mathrm{M} 13 \mathrm{mp} 8$, and single-stranded phage DNA prepared. A complementary strand was synthesized containing $\left.{ }^{32} \mathrm{P}\right] \mathrm{dGMP}$ and bromodeoxyuracil, as a substitute for thymidine. Restriction enzyme cleavage released a small labeled fragment that was incubated with affinity-purified protein fractions under

Table 1. Purification of EBP1 from HeLa cell nuclear extracts

\begin{tabular}{lccccr}
\hline Fraction & $\begin{array}{l}\text { Protein } \\
(\mathrm{mg})\end{array}$ & Units $^{\mathrm{a}}$ & $\begin{array}{l}\text { Yield } \\
\text { (\%) }\end{array}$ & $\begin{array}{l}\text { Specific activity } \\
\text { (units/mg/protein) }\end{array}$ & -Fold purification \\
\hline Crude nuclear extract & 861 & 84,378 & 100 & 98 & 1 \\
DEAE pool & 77 & 36,400 & 43 & 473 & 5 \\
First ds SVl pool & 1.3 & 25,480 & 30 & 19,600 & 210 \\
Second ds SV1 pool & 0.08 & 19,110 & 22.6 & 238,875 & 2,560 \\
Third ds SV1 pool & 0.008 & 11,275 & 13.4 & $1,409,375$ & 15,150 \\
\hline
\end{tabular}

a One unit of activity represents the retention of 15 fmole specific DNA bound in the DNA-protein complexes in the gel electrophoresis DNA-binding assay.

$\mathrm{b}$ Estimate based on comparative silver staining. 
A

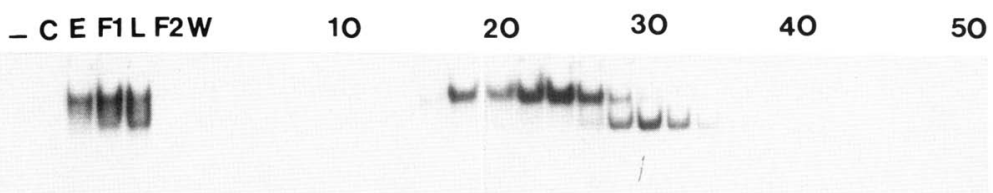

Figure 3. Fractionation of HeLa nuclear extract. Dialyzed nuclear extract was loaded onto a DEAE-Sepharose CL-6B column, and bound proteins eluted with a linear gradient of $0.05-0.4$ $\mathrm{M} \mathrm{NaCl}$. Fractions were incubated with ${ }^{32} \mathrm{P}-1 \mathrm{a}-$ beled SV1 double-stranded synthetic oligonucleotide under standard conditions (Materials and methods), and DNA-protein complexes resolved on $6 \%$ polyacylamide gels. Gels were either dried down and autoradiographed $|A|$ or enhancer-protein-binding activity quantified by excising bound species from the gels and determining the radioactivity present by Cer-

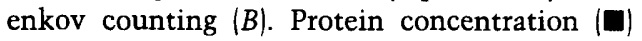
was determined by the method of Bradford (1976). Fractions sampled are indicated below each panel. $(C)$ Cytoplasmic extract; $(E)$ nuclear extract $_{i}(F 1)$ material passing through the first DEAE-Sepharose CL-6B column; (L, F2, W) column load, flow through, and $0.05 \mathrm{M} \mathrm{NaCl}$ wash from the second DEAE-Sepharose CL-6B column, respectively.

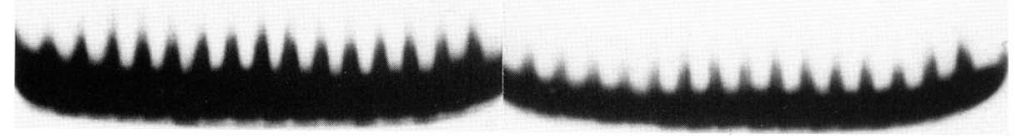

B

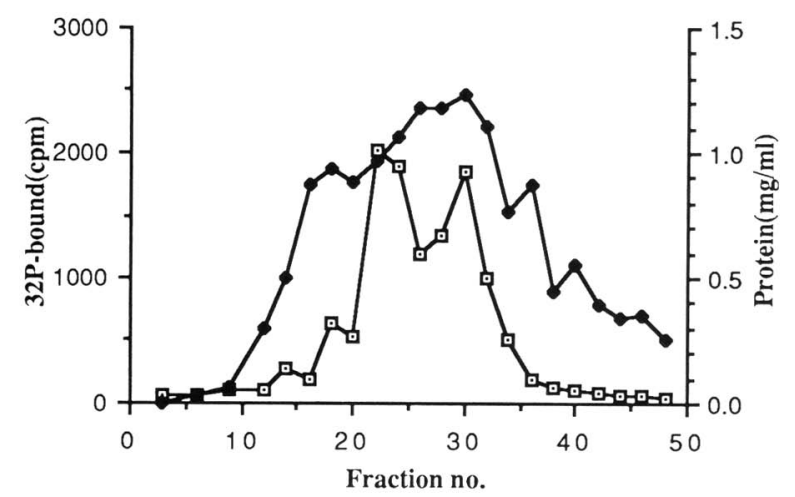

conditions similar to those employed in the gel electrophoresis DNA-binding assay. Once equilibration had been reached, the samples were irradiated with ultraviolet (UV) light, digested with nucleases, and analyzed by autoradiography after SDS-polyacrylamide gel electrophoresis. When the products of the cross-linking reactions were analyzed without nuclease treatment, it was evident that the labeled oligonucleotide had been crosslinked to a polypeptide present in the binding reaction (Fig. 5). Treatment of the cross-linked products with DNase I and micrococcal nuclease, prior to gel electrophoresis, decreased the apparent molecular weight of the labeled species and identified a polypeptide with a mo-

lecular weight of $\sim 60,000$ (Fig. 5). The labeled species accumulated with increased irradiation (Fig. 5), but no cross-linking was observed if bovine serum albumin was substituted for EBP1 in the DNA-binding reaction (data not shown). Addition of an excess of unlabeled SV1 oligonucleotide to the binding reaction abolished crosslinking, whereas inclusion of double-stranded oligonucleotides containing the binding sites for NFI or NFIII had little effect (Fig. 5). These data indicate that a polypeptide of $\sim 60,000$ is responsible for specific binding to the GT-I region of the SV40 enhancer and is the major component present in our most highly purified preparations.

Figure 4. Recognition site affinity chromatography of EBP1. (A) Poly[d(G-C)] and poly[d(A-T)] were added to the DEAE-Sepharose fractions containing EBP1 activity and passed over an affinity matrix composed of tandemly ligated SVI oligonucleotides covalently linked to cyanogen-bromide-activated Sepharose 4B. Bound proteins were eluted with 1.0 $\mathrm{M} \mathrm{NaCl}$, and fractions assayed for EBPl activity. (L) Load; (FT) flowthrough; (W) wash; (1-8) fractions from $1 \mathrm{M} \mathrm{NaCl}$ elution. (B) Fractions from each stage of the EBP1 purification were precipitated with TCA and analyzed by SDS-polyacrylamide gel electrophoresis and silver staining. Equivalent amounts (28 units) of each affinity column eluate were applied to each lane. The molecular weights of the marker proteins are indicated. (D) DEAE-Sepharose fractions; $(1,2$, and 3$)$ first, second, and third-

A

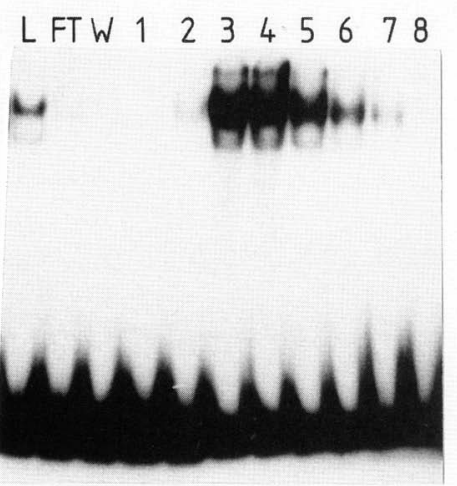

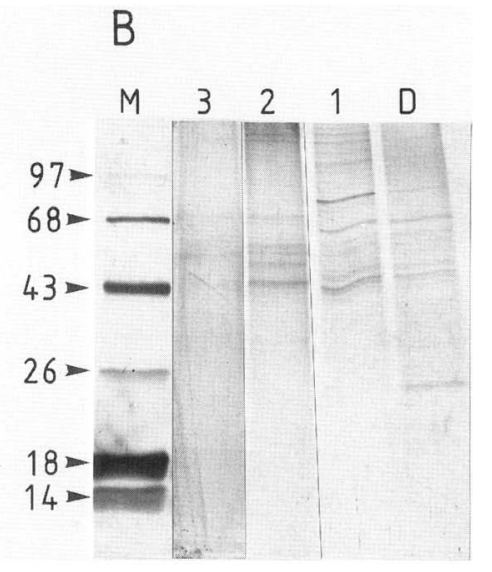
round affinity column eluates; (M) protein molecular weight standards. 


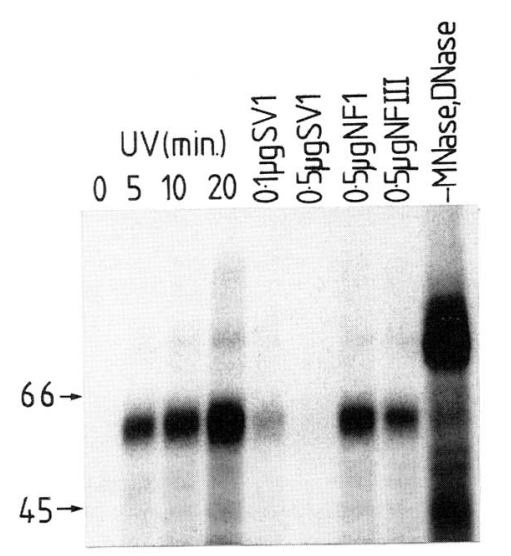

Figure 5. Bromodeoxyuracil cross-linking of EBP1 to its binding site on the SV40 genome. A bromodeoxyuridine-substituted, ${ }^{32} \mathrm{P}$-labeled double-stranded DNA fragment containing the EBP1-binding site was prepared as described in Materials and methods. Probe DNA was incubated with affinity-purified EBP1 under conditions employed in the gel electrophoresis DNA-binding assay. Once equilibrium was reached, samples were irradiated with UV light, followed by treatment with DNase I and micrococcal nuclease, as indicated. Reaction products were fractionated on $10 \%$ SDS-polyacrylamide gels and visualized by autoradiography. The positions of the 66,000 and $45,000-\mathrm{m}$.w. protein standards are indicated by the arrows. UV irradiation, in the absence of competitor, was for $0,5,10$, and $20 \mathrm{~min}$. In the competition analysis, EBP1 was allowed to bind in the presence of $0.1 \mu \mathrm{g} \mathrm{SV1}, 0.5 \mu \mathrm{g} \mathrm{SVI}, 0.5 \mu \mathrm{g} \mathrm{NFI}$ or 0.5 $\mu \mathrm{g}$ NFIII double-stranded oligonucleotides prior to UV irradiation for $10 \mathrm{~min}$. Reaction products that were UV irradiated for 10 min without subsequent DNase I or micrococcal nuclease digestion are also shown (-MNase, DNase).

\section{DNA-binding specificity of purified EBP1}

DNase I protection experiments were employed to define the binding site of the purified protein on the SV40 enhancer. A $3^{\prime}$ 32P-labeled DNA fragment containing SV40 enhancer sequences was incubated with the purified preparations of EBP1, subjected to DNase I digestion, and the cleavage products were displayed. The purified protein protects the region from 230 to 250 on the SV40 enhancer from cleavage with DNase I (Fig. 6). Protection against DNase I cleavage of a similar region between positions 233 and 252 on the opposite strand (Fig. 2) was observed with partially purified nuclear extracts, indicating that the protein we have purified is probably responsible for the binding activity observed in the nuclear extract. This conclusion was strengthened by the observations that the SV1 and SV1.M2 oligonucleotides can compete for binding of the factor, whereas the SV1.M1 oligonucleotide is incapable of competing (Fig. 6).

Interaction of the purified factor with ${ }^{32} \mathrm{P}$-labeled SV1 double-stranded oligonucleotide was monitored in the gel electrophoresis DNA-binding assay. Whereas unlabeled SV1 oligonucleotide could compete efficiently for the binding of the purified factor, the SVI.M1 oligonucleotide with $G \rightarrow C$ changes at positions 244 and 245

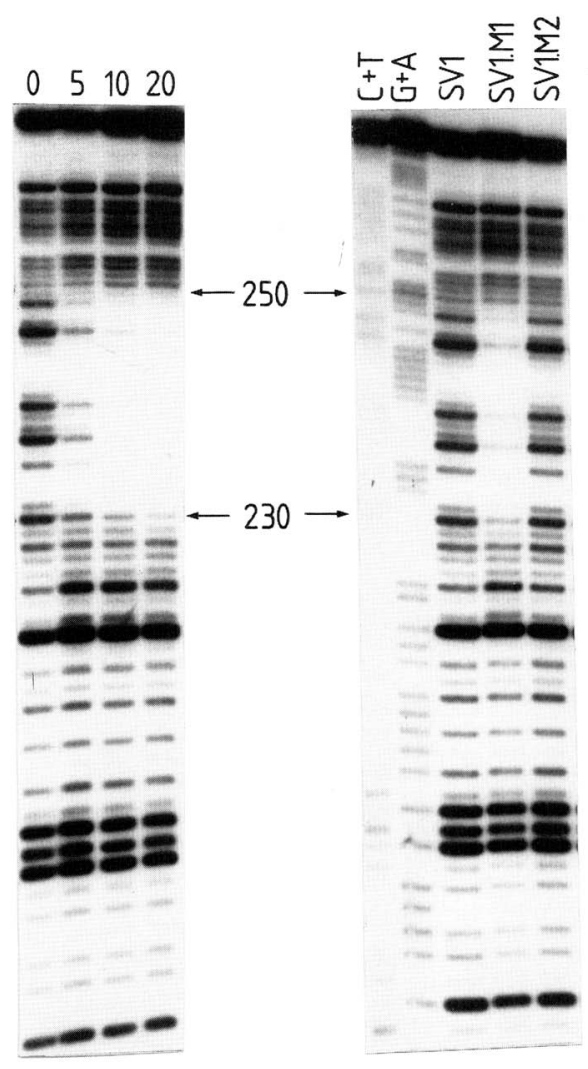

Figure 6. DNase I protection of the SV40 enhancer by affinitypurified EBP1. The BamHI-PvuII fragment from pUC1X72, 3' ${ }^{32} \mathrm{P}$ labeled at the BamHI site, was incubated with $0,5,10$, or 20 $\mu l$ of affinity-purified EBP1, as described in Materials and methods. Competition assays were carried out in which $10 \mu \mathrm{l}$ of EBP1 was incubated with labeled probe in the presence of $500 \mathrm{ng}$ of unlabeled SV1, SV1.M1, and SV1.M2 double-stranded oligonucleotide. After treatment with DNase I, reaction products were electrophoresed in a $6 \%$ denaturing polyacrylamide gel. $\mathrm{C}+\mathrm{T}$ - and $\mathrm{A}+\mathrm{G}$-specific cleavage reactions of the labeled fragment were electrophoresed in parallel as markers.

was unable to do so. This was also true of the SV1.M3 oligonucleotide, which contained $\mathrm{C} \rightarrow \mathrm{G}$ alterations at position 237 and 238 (Fig. 7A). Zenke et al. (1986) constructed a series of clustered point mutants in the SV40 enhancer that have been used extensively to study enhancer function. We therefore examined the binding of EBP1 to three of these scanning point mutants, pA12, pA15, and pA16, in the gel electrophoresis DNA-binding assay. Affinity-purified EBP1 was incubated with ${ }^{32} \mathrm{P}-\mathrm{la}-$ beled DNA fragments containing one copy of the wildtype or mutated SV40 enhancer and DNA-protein complexes resolved by native polyacrylamide gel electrophoresis. Whereas the mutation present in pAl6 has no effect on EBP1 binding, the mutations present in p12 and pA15 reduce EBP1 binding to an undetectable level (Fig. 7B). Thus, the purified protein makes sequence-specific DNA contacts within the GT-I motif, at positions 244 and 245, and in the TC-II motif, at positions 237 and 238 (Fig. 7C). 
Figure 7. DNA-binding specificity of affinity-purified EBP1. (A) Competition analysis of EBPI binding. Reactions contained 0.5 ng of ${ }^{32}$ P-labeled, double-stranded SVI oligo* nucleotide, $1.0 \mu \mathrm{g}$ of unlabeled poly[d/A$\mathrm{T})]$ : poly $[\mathrm{d}(\mathrm{C}-\mathrm{G})]$, and $1.0 \mu \mathrm{l}$ of affinity-purified EBPI (lane - contained no EBP1). In addition, reactions contained 25 (lanes 1), 50 (lanes 2), or 100 (lanes 3) ng of unlabeled, double-stranded SV1, SV1.M1, or SV1.M3 oligonucleotides. Reaction products were analyzed on $6 \%$ polyacrylamide gels. $(B)$ Binding of purified EBP1 to pA mutants. DNA frag. ments containing wild-type and mutant enhancers were excised by BamHI and PvuII digestion and $3^{\prime}$-end labeled with ${ }^{32} \mathrm{P}$ at the BamHI site. Labeled DNA was incubated with EBPl (as described in $A$ ), and DNA-protein complexes resolved on a $6 \%$ polyacrylamide gel. DNA templates utilized are indicated above each lane; (-) EBP1 was omitted from the binding reactions. (C) DNA sequence of the GT-I and TC-II motifs and summary of EBP1 binding to mutated DNAs. Bases altered in the mutants are indicated; dashes represent unchanged bases.

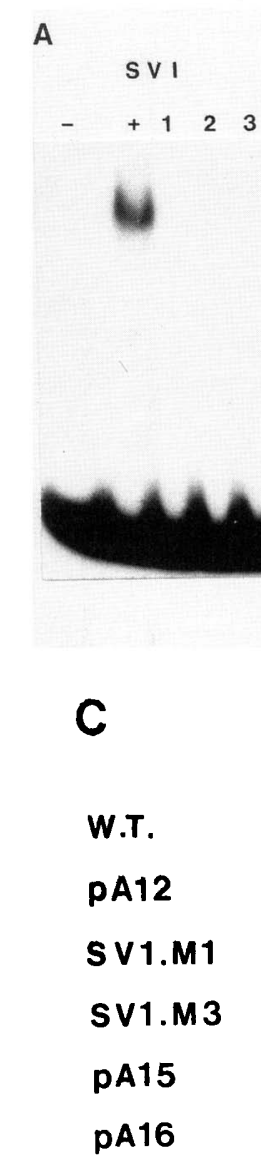

AP-3, from HeLa cells, which bind close to this region, have been described recently (Imagawa et al. 1987; Mitchell et al. 1987). EBP1 can be distinguished from both of these factors by comparing the ability of the different proteins to bind to mutated templates. The plasmid pA12 contains a mutated SV40 enhancer element in which the sequence $5^{\prime}$-TGG-3' $(246-244)$ is altered to $5^{\prime}$-GTT-3' (Zenke et al. 1986). AP-2 binds normally to this fragment (Mitchell et al. 1987), whereas EBP1 binding is abolished (Fig. 7), thus indicating that EBP1 and AP-2 have distinct recognition sites. EBP1 binding is also abolished by the mutation present in pA15 (Fig. 7), in which 5'-CCC-3' (237-235) is altered to 5'-AAA-3' (Zenke et al. 1986), whereas AP-3 binds normally to this template (Mitchell et al. 1987). This finding therefore distinguishes EBP1 from AP-3. We have recently established the importance of these $\mathrm{mu}$ tated bases in a detailed contact point analysis of EBP1 binding to the SV40 enhancer and have shown that the Gs present on one strand at positions 244 and 245 and on the opposite strand at positions 237 and 238 are in close contact with the EBPl protein (L. Clark, J. Nicholson, and R.T. Hay, in prep.).

The role of EBP1 in transcriptional activation of the SV40 genome is suggested by correlating the in vivo activity of wild-type and mutated enhancers with EBP1 binding. Tandemly ligated copies of an oligonucleotide containing the EBP1-binding site can function as a tran- 
scriptional enhancer when inserted into an appropriate expression vector (Ondek et al. 1987; R.M. Pollock, L. Clark, and R.T. Hay, unpubl.). Mutation of the two Gs at positions 244 and 245 abolished the enhancer activity of the ligated oligonucleotides (Ondek et al. 1987) and also abolished binding of EBP1 (Figs. 1, 2, 6, and 7). Nomiyama et al. (1987) have examined the activity of the pA series of triple point mutants in the SV40 enhancer (Zenke et al. 1986) in a variety of cell types and correlated the activity of the various enhancer motifs with the presence of trans-acting factors. One cell-type-specific protein, GT-IC (probably equivalent to AP-3), present in HeLa but not in MCPII cells, binds to the GT-I motif in the SV40 enhancer (Xiao et al. 1987a). An additional cell-type-specific protein, TC-IIA, and a ubiquitous protein, TC-IIB, are reported to bind to the TC-II motif (Nomiyama et al. 1987). TC-IIA and TC-IIB appear to have very similar recognition sites to that of EBP1. The mutation present in pA12 (described above) abolishes binding of all of these proteins and has a severe deleterious effect on transcription in all of the cell lines tested (Nomiyama et al. 1987). Mutations in the GT-I motif (pAl0 and pAll), which eliminate GT-IC binding but have no effect on the binding of TC-IIA, TC-IIB, or EBP1, have no effect in MCPII cells where GT-IC is absent. In HeLa cells, mutations pAl0 and pA11 have only a minimal effect on enhancer activity, whereas mutation pA15, which abolishes binding of TC-IIA, TC-IIB, and EBP1, reduces transcription in vivo to $40-50 \%$ of wild type. Because binding of GT-IC (AP-3) and EBP1 (TC-IIB) is eliminated by pA12, these proteins may compete for the same binding site in HeLa cells. The minimal effect of mutations pAlO and pAll in HeLa cells suggests that EBP1 (TC-IIB) is bound to the template in preference to GT-IC. Elimination of EBP1 (TC-IIB) binding by mutant pAl5 permits the binding of GT-IC (AP-3), which also appears to stimulate transcription, because a template that contains both the pA10 and pA15 mutations gives only $5 \%$ enhancer activity in HeLa cells (Nomiyama et al. 1987). These data are summarized in Figure 8, which shows the disposition on the SV40 enhancer of the transcription factors AP-2, AP-3 (Mitchell et al. 1987), and EBP1.

The binding site for EBP1 clearly overlaps the binding sites for both AP-2 and AP-3, as discussed above, and binding of EBP1 may exclude binding of AP-2 and AP-3, or vice versa. This poses the question of which proteins are bound to the enhancer in vivo in cell types other than HeLa. Answering this question is important because it has been shown that the regions bound by AP-3 and EBP1 can act to mediate the transcriptional response to phorbol esters (Chiu et al. 1987). Thus, the multimerized C element described by Ondek et al. (1987), which is equivalent to the SV1 oligonucleotide used in this study, can act as a phorbol-ester-responsive element (Chiu et al. 1987). In addition, mutation of the two Gs at positions 244 and 245 destroys the ability of the multimerized oligonucleotides to act as a phorbol-ester-inducible element (Chiu et al. 1987) and, as we have shown here, abolishes the ability of EBP1 to recognize its
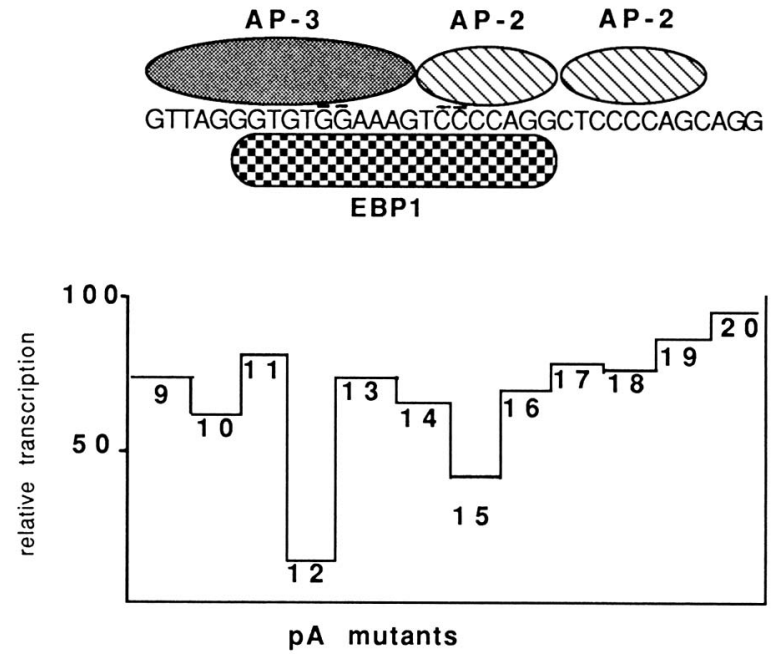

Figure 8. Disposition of transcription factors Ap-2, AP-3, and EBPl on the SV40 enhancer. The DNase I footprint boundaries for AP-2 and AP-3 on the SV40 enhancer DNA sequence are from Mitchell et al. (1987), and EBP1 is from this study. However, it should be stressed that these boundaries probably represent an overestimate of the region occupied by the DNAbinding proteins, because DNase I is a relatively large molecule and requires an extended binding surface for DNA cleavage (Suck et al. 1988). The effects of mutations in this region on transcription in vivo are from Zenke et al. (1986) (with permission). Altered bases in the mutated SVI oligonucleotides SV1.M1 and SV1.M3, which abolish EBP1 binding, are underlined.

binding site. The binding site for EBP1 is similar to that described for the inducible factor NF-kB (Sen and Baltimore $1986 \mathrm{a}, \mathrm{b} \mid$ and the apparently ubiquitous factor H2TFI or KBFI (Baldwin and Sharp 1987, 1988; Israel et al. 1987; Yano et al. 1987). These proteins may constitute a family of related, but distinguishable, proteins that recognize similar DNA sequences. Synthetic oligonucleotides containing the NF-kB- and H2TFI-binding sites compete for EBP1 binding with similar efficiency to the SV1 oligonucleotide (L. Clark and R.T. Hay, in prep.). However, EBP1 can be distinguished from NF-kB and H2TFI/KBFI by a number of criteria. NF-kB binds to a site in the immunoglobulin $\kappa$ light-chain enhancer (Sen and Baltimore 1986a) but unlike EBP1, which is constitutively produced in HeLa cells, NF-kB binding activity is normally restricted to B cells and its activity is only apparent in other cell types after stimulation with agents such as bacterial lipopolysaccharide and phorbol esters. This induction of NF-kB-binding activity is evident even when the stimulation is carried out in the presence of inhibitors of protein synthesis. Therefore, it appears that prior to induction, NF-kB exists in the cell in an inactive form that is converted to an active form by a post-translational modification undefined as yet (Sen and Baltimore 1986b). We have also found that NF- $k B$, induced in mouse B cells, binds to the SVl oligonucleotide, but the DNA-protein complex formed has an increased electrophoretic mobility when compared to the EBPl/SVl complex (L. Clark, G. McGarvie, W. Cushley, and R.T. Hay, unpubl.). 
The distinguishing features of $\mathrm{H} 2 \mathrm{TFI} / \mathrm{KBFI}$ are its high affinity for the sequence

\section{-TGGGGATTCCCCA- - ACCCCTAAGGGGT-}

that is found in the enhancers of the mouse $\mathrm{H}-2$ and $\beta 2$ microglobulin genes and its unique pattern of methylation interference (Baldwin and Sharp 1988; Israel et al. 1987). As mentioned previously, EBPl binds the SVl and H2TFI/KBFI sequences with equal affinities, whereas H2TFI/KBFI binds the sequence indicated above with an efficiency 20-fold higher (Baldwin and Sharp 1988). We have recently carried out a detailed contact point analysis of the interactions of EBP1 with its binding site on the SV40 enhancer and have demonstrated that the patterns of methylation interference are distinct from those obtained with H2TFI/KBFI. Methylation interference experiments with $\mathrm{H} 2 \mathrm{TFI} / \mathrm{KBFI}$ indicate that all of the Gs in the sequence interfere with binding when methylated (Israel et al. 1987; Baldwin and Sharp 1988). This is in contrast to the pattern obtained with EBP1, where the outermost $G$ in the sequence do not interfere with binding when modified (L. Clark, J. Nicholson, and R.T. Hay, in prep.). An attractive explanation of these differences is that EBP1, NF-kB, and H2TFI/KBFI represent the different modified forms of the same DNA-binding protein. The recent cloning of the gene coding for the DNA-binding domain of a protein that binds to the NF-kB and H2TFI recognition sequences lends support to this idea (Singh et al. 1988).

Although we have no direct evidence for post-translational modification of EBP1, this may account for the observation that two distinct DNA-protein complexes can be detected at early stages of purification. Both complexes have the same DNA-binding specificity and are cross-linked to polypeptides of identical molecular weight (data not shown). After affinity purification, however, only the more slowly migrating complex is detected. This may result from instability of the factor responsible for formation of the faster-migrating DNAprotein complex, modification of the factor during extraction and purification, or removal of associated factors during purification.

The SV40 enhancer, although only $\sim 100 \mathrm{bp}$ long, is an extremely complex transcriptional control unit containing the binding sites for a large number of proteins (Wildeman et al. 1986). At one level, the enhancer consists of two large domains, which have very little enhancing activity in isolation, but when combined act synergistically to give a large increase in activity (Zenke et al. 1986). Within each domain, identifiable sequence motifs represent the binding sites for regulatory proteins. In general, single copies of these motifs do not have enhancer activity, but enhancer activity is observed when the motifs are multimerized or combined with other motifs. This suggests that a large nucleoprotein complex is formed in which DNA sequence-specific binding proteins interact with their recognition sites on the genome and with the transcriptional machinery to initiate RNA synthesis directed by RNA polymerase II at the promoter, which may be some distance from the enhancer element.

Understanding the mechanism of enhancer action will require the reconstitution of this process in vitro. Purification of individual transcription factors clearly will be required to attain this goal, and the purification of EBP1 is a step in that direction.

\section{Materials and methods}

Cell culture

HeLa cells were grown in suspension in Earle's minimal essential medium (GIBCO), supplemented with $5 \%$ newborn calf serum (Seralabs).

\section{Plasmids and labeled fragments}

Plasmid $\mathrm{pUC1X} 72$ contains the $\mathrm{SV} 40$ regulatory region inserted between the EcoRI and BamHI sites of pUCl3. The regulatory region was generated from an EcoRI-BamHI fragment of pMKD 231 (Everett et al. 1983), with one copy of the 72-bp repeat element deleted. Plasmid pMKD 231 was a kind gift from R.D. Everett, MRC Institute of Virology, Glasgow, Scotland. Plasmids pA12, pA15, and pA16 (Zenke et al. 1986) were generously provided by P. Chambon, Centre National de la Recherche Scientifique (CNRS), Strasbourg, France. Labeled fragments containing one copy of the 72-bp element were prepared by first cleaving pUC1X72 with BamHI. [ $\gamma^{-32}$ ] ATP (Amersham; sp. act. $3000 \mathrm{Ci} / \mathrm{mmole} /$ and polynucleotide kinase were used to $5^{\prime}$-end label dephosphorylated DNA. $\left[\alpha^{-32} \mathrm{P}\right] \mathrm{dATP}$ (Amersham; sp. act. $3000 \mathrm{Ci} / \mathrm{mmole}$ ), the other three unlabeled dNTPs, and the large fragment of Esherichia coli DNA polymerase I were used to $3^{\prime}$-end label DNA. Secondary cleavage with PvuII or EcoRI generated fragments of 97 and $173 \mathrm{bp}$, respectively, both of which contain one copy of the SV40 enhancer element. Fragments were purified on $6 \%$ polyacrylamide gels and electroeluted (Hay and DePamphilis 1982). Complementary, synthetic oligonucleotides were annealed by first heating to $100^{\circ} \mathrm{C}$ in $0.1 \mathrm{M} \mathrm{NaCl}, 10 \mathrm{mM}$ Tris $-\mathrm{HCl} / \mathrm{pH}$ $8.0 \mid$, and $1 \mathrm{mM}$ EDTA, followed by slow cooling to $16^{\circ} \mathrm{C}$. The double-stranded oligonucleotides were labeled with $\left[{ }^{32} \mathrm{P}\right] \mathrm{dATP}$, as described above. Oligonucleotides were synthesized on an Applied Biosystems model 381A DNA synthesizer, and all contained BamHI-BgIII compatible termini.

\section{Gel electrophoresis DNA-binding assay}

Assays contained $0.5-1.0 \mathrm{ng}$ labeled probe $(\sim 10,000 \mathrm{cpm}), 1 \mu \mathrm{g}$ of unlabeled DNA (equimolar amounts of poly[d(AT)] : poly[d(G-C)]), $20 \mathrm{mM}$ HEPES $\mathrm{NaOH}(\mathrm{pH} 7.5), 1 \mathrm{mM}$ dithiothreitol (DTT), $1 \mathrm{~mm}$ EDTA, $10 \%$ glycerol, $100 \mathrm{~mm} \mathrm{NaCl}$, $0.05 \%$ NP- 40 , and $1-2 \mu$ l of protein fraction in a final reaction volume of $20 \mu \mathrm{l}$. Binding reactions were allowed to proceed to equilibrium for $20 \mathrm{~min}$ at $20^{\circ} \mathrm{C}$, after which time $5 \mu \mathrm{l}$ of $50 \%$ glycerol, $25 \mathrm{mM}$ HEPES $\mathrm{NaOH}(\mathrm{pH} 7.5)$, and $0.1 \%$ bromphenol blue were added, and the entire reaction loaded onto $6 \%$ (80:1 acrylamide/bisacrylamide) polyacrylamide gels containing $0.5 \times$ TBE [50 mM Tris-borate, $0.5 \mathrm{~mm}$ EDTA (pH 8.3)]. Electrophoresis was carried out at $200 \mathrm{~V}$ for $1 \mathrm{hr}$. Gels were fixed in $10 \%$ acetic acid, dried, and exposed to Fuji RX X-ray film at $-70^{\circ} \mathrm{C}$, with an intensifying screen (Dupont). As a rapid and quantitative means of determining the yield of enhancerbinding activity at each step during the fractionation, bands corresponding to bound DNA were excised from the gels, and their radioactivity was determined by Cerenkov radiation 
counting. One unit of activity represents the retention of 15 fmole specific DNA bound in the DNA-protein complexes in the standard gel electrophoresis DNA-binding assay.

\section{UV cross-linking}

Double-stranded SV1 oligonucleotide was cloned into the BamHI site of bacteriophage M13mp8. DNA synthesis, primed by the 17-mer sequencing primer, on single-stranded M13 recombinant DNA was catalyzed by the large fragment of $E$. coli DNA polymerase $I$ in the presence of dTTP, dATP, $\left[\alpha{ }^{-32} \mathrm{P}\right] \mathrm{dGTP}$, and 5-bromo-2'deoxyuridine triphosphate (Pharmacia). DNA was digested with EcoRI and PstI, and the small fragment containing the EBPl-binding site was purified on $6 \%$ polyacrylamide gels and electroeluted (Hay and DePamphilis 1982). Binding reactions were prepared in the same way as for gel electrophoresis DNA-binding assays in a total reaction volume of $50 \mu \mathrm{l}$. Once equilibrium was reached, samples were irradiated on a TM-36 Transilluminator (UVP, Inc.)-peak wavelength, $302 \mathrm{~nm}$; peak intensity, $7.0 \mathrm{~mW} / \mathrm{cm}^{2}$ - the samples were packed on ice to maintain a constant temperature throughout irradiation. Digestion with 0.17 units/ $\mu$ l DNase I (Amersham) and/or 0.07 units/ $\mu \mathrm{l}$ micrococcal nuclease (Pharmacia) was then carried out for $30 \mathrm{~min}$ at $37^{\circ} \mathrm{C}$ after addition of $\mathrm{MgCl}_{2}$ and $\mathrm{CaCl}_{2}$ to a final concentration of $3 \mathrm{mM}$. Reaction products were electrophoresed on $10 \%$ SDS-polyacrylamide gels and visualized by autoradiography.

\section{DNase I protection}

Reactions contained $0.5-1.0$ ng labeled probe $(\sim 10.000 \mathrm{cpm}), 1$ $\mu \mathrm{g}$ unlabeled carrier DNA, poly[d(A-T)] : poly[d(C-G)], $25 \mathrm{~mm}$ HEPES $\mathrm{NaOH}(\mathrm{pH} 7.5), 100 \mathrm{~mm} \mathrm{NaCl}$, and various amounts of protein fractions, containing $50 \%$ glycerol, $1 \mathrm{mM}$ DTT, $1 \mathrm{~mm}$ EDTA, and $0.1 \% \mathrm{NP}-40$ in a total reaction volume of $50 \mu \mathrm{l}$. After $20 \mathrm{~min}$ at $20^{\circ} \mathrm{C}, 0.5$ units of DNase I (Amersham), in a final concentration of $4 \mathrm{mM} \mathrm{MgCl}_{2}$, was added, and the reaction allowed to proceed for $60 \mathrm{sec}$ at $20^{\circ} \mathrm{C}$, after which time $60 \mu \mathrm{l} 0.6$ M NaOAc, 20 mM EDTA was added. The DNA was then extracted once with phenol and once with chloroform, ethanolprecipitated, washed with $70 \%$ ethanol, dried, and redissolved in $10 \mu \mathrm{l} 98 \%$ formamide, $20 \mathrm{mM} \mathrm{NaOH}, 1 \mathrm{~mm}$ EDTA with bromphenol blue and xylene cyanol FF. DNA was denatured at $100^{\circ} \mathrm{C}$ for $2 \mathrm{~min}$, cooled on ice, and reaction products electrophoresed on $6 \%$ polyacrylamide gels containing $50 \%$ urea. Gels were fixed in $10 \%$ acetic acid, dried, and exposed to X-ray film (Hyperfilm MP; Amersham) at $-70^{\circ} \mathrm{C}$ in the presence of an intensifying screen. Sequence markers were prepared by subjecting end-labeled fragments to $\mathrm{G}+\mathrm{A}$ - or $\mathrm{C}+\mathrm{T}$-specific cleavage reactions (Maxam and Gilbert 1980).

\section{Purification of EBP1 from HeLa nuclear extract}

Uninfected HeLa cells $\left(2 \times 10^{10}\right)$ were fractionated into nuclei and cytosol, as described previously (Challberg and Kelly 1979). After washing three times with $25 \mathrm{mM}$ HEPES NaOH (pH 7.5), $5 \mathrm{mM} \mathrm{KCl}, 0.5 \mathrm{mM} \mathrm{MgCl}_{2}, 0.5 \mathrm{~mm}$ DTT, $0.2 \mathrm{M}$ sucrose, and 1 $\mathrm{mM}$ phenylmethylsulfonyl fluoride (PMSF), the nuclei were resuspended in the same buffer containing $0.35 \mathrm{M} \mathrm{NaCl}$ and stirred on ice for $30 \mathrm{~min}$. Particulate material was removed by centrifugation at $100,000 \mathrm{~g}$ for $60 \mathrm{~min}$. The supernatant was adjusted to $0.3 \mathrm{M} \mathrm{NaCl}$ and applied to a DEAE-Sepharose CL-6B (Pharmacia) column equilibrated with buffer A [25 mM HEPES $\mathrm{NaOH}$ (pH 7.5), $1 \mathrm{~mm}$ EDTA, $1 \mathrm{~mm}$ DTT, 0.1\% NP-40, $1 \mathrm{~mm}$ PMSF, $20 \%$ glycerol] containing $0.3 \mathrm{M} \mathrm{NaCl}$. The flowthrough was dialyzed against buffer A containing $50 \mathrm{mM} \mathrm{NaCl}$, and insoluble material was removed by centrifugation at $100,000 \mathrm{~g}$ for
$30 \mathrm{~min}$. The clarified extract was then applied to a second DEAE-Sepharose column equilibrated with buffer A containing $50 \mathrm{mM} \mathrm{NaCl}$. After washing with two column volumes of equilibration buffer, the column was developed with a linear gradient of $50-400 \mathrm{mM} \mathrm{NaCl}$. Fractions containing EBP1 activity were pooled, mixed with carrier DNA (poly[d(A-T)]: poly[d(C-G) $)$, and subjected to three rounds of recognition site affinity chromatography on DNA affinity columns prepared with the sequence

\section{5'-GATCTAGGGTGTGGAAAGTCCCG-3' 3'-ATCCCACACCTTTCAGGGCCTAG-5'}

essentially as described by Kadonaga and Tjian (1986), except that 400,50 , and $5 \mu \mathrm{g}$ of carrier was added to the first, second, and third round affinity loads, respectively, and $3 \mathrm{~mm}$ n-octyl glucopyranoside (Sigma) was included in affinity chromatography buffers (Treisman 1987). Protein concentrations were determined by the method of Bradford (1976). Protein was precipitated in $10 \%$ TCA, washed with $80 \%$ acetone, resuspended in SDS/ $\beta$-mercaptoethanol, and immersed in a boiling water bath for $3 \mathrm{~min}$ prior to electrophoresis in thin $(0.3 \mathrm{~mm})$ SDS-polyacrylamide gels and silver staining (Bio-Rad) (Laemmli 1970; Oakley et al. 1980).

\section{Acknowledgments}

This work was supported by grants from the Medical Research Council and the Society for General Microbiology. L.C. is a recipient of a Science and Engineering Research Council studentship for postgraduate training. We are extremely grateful to I. Nicholl for the provision of HeLa cells and oligonucleotides and to B. Blythe for photography. Thanks are also due to Professor W.C. Russell, Dr. C.J. Watson, and Dr. M.G. Burdon for helpful comments on the manuscript.

\section{References}

Angel, P., M. Imagawa, R. Chiu, B. Stein, R.J. Imbra, H.J. Rahmsdorf, C. Jonat, P. Herrlich, and M. Karin. 1987. Phorbol ester-inducible genes contain a common cis element recognized by a TPA-modulated trans-acting factor. Cell 49: 729-739.

Baldwin, A.S., Jr., and P.A. Sharp. 1987. Binding of a nuclear factor to a regulatory sequence in the promoter of the mouse $\mathrm{H}-2 \mathrm{~Kb}$ class I major histocompatibility gene. Mol. Cell. Biol. 7: 305-313.

1988. Two transcription factors, NF-kB and H2TFI, interact with a single regulatory sequence in the class I major histocompatibility complex promoter. Proc. Natl. Acad. Sci. 85: 723-727.

Banerii, J., L. Olsen, and W. Schaffner. 1983. A lymphocyte-specific cellular enhancer is located downstream of the joining region in immunoglobulin heavy chain genes. Cell 33: 729740.

Banerii, J., S. Rusconi, and W. Schaffner. 1981. Expression of a $\beta$-globin gene is enhanced by remote SV40 DNA sequences. Cell 27: 299-308.

Barrett, P., L. Clark, and R.T. Hay. 1987. A cellular protein binds to a conserved sequence in the adenovirus type 2 enhancer. Nucleic Acids Res. 15: 2719-2735.

Bradford, M.M. 1976. A rapid and sensitive method for the quantitation of microgram quantities of protein utilizing the principle of protein-dye binding. Anal. Biochem. 72: 248254.

Challberg, M.D. and T.J. Kelly. 1979. Adenovirus DNA replica- 
tion in vitro. Proc. Natl. Acad. Sci. 76: 655-659.

Chandler, V.L., B.A. Maler, and K.R. Yamomoto. 1983. DNA sequences bound specifically by glucocorticoid receptor in vitro render a heterologous promoter hormone responsive in vivo. Cell 33: 489-499.

Chiu, R., M. Imagawa, R.J. Imbra, J.R. Bockoven, and M. Karin. 1987. Multiple cis- and trans-acting elements mediate the transcriptional response to phorbol esters. Nature 329: 648651.

Davidson, I., C. Fromental, P. Augereau, A. Wildeman, M. Zenke, and P. Chambon. 1986. Cell-type specific protein binding to the enhancer of simian virus 40 in nuclear extracts. Nature 323: 544-548.

Everett, R.D., D. Baty, and P. Chambon. 1983. The repeated GC-rich motifs upstream from the TATA box are important elements of the SV40 early promoter. Nucleic Acids Res. 11: $2447-2464$

Fried, M. and D.M. Crothers. 1981. Equilibria and kinetics of lac repressor-operator interactions by polyacylamide gel electrophoresis. Nucleic Acids Res. 9: 6505-6525.

Galas, D.J. and A. Schmitz. 1978. DNase footprinting: A simple method for the detection of protein-DNA binding specificity. Nucleic Acids Res. 5: 3157-3170.

Garner, M.M. and A. Revzin. 1981. A gel electrophoresis method for quantifying the binding of proteins to specific DNA regions. Applications to components of the E. coli lactose operon regulatory system. Nucleic Acids Res. 9: 30473060.

Gillies, S.D., S.L. Morrison, V.T. Oi, and S. Tonegawa. 1983. A tissue-specific transcription enhancer element is located in the major intron of a rearranged immunoglobulin heavy chain gene. Cell 33: 717-728.

Goodbourn, S., H. Burstein, and T. Maniatis. 1986. The human $\beta$-interferon gene enhancer is under negative control. Cell 45: $601-610$.

Goodbourn, S., K. Zinn, and T. Maniatis. 1985. Human $\beta$-interferon gene expression is regulated by an inducible enhancer element. Cell 41: 509-520.

Hay, R.T. and M.L. DePamphilis. 1982. Initiation of SV40 DNA replication in vivo: Location and structure of $5^{\prime}$ ends of DNA synthesized in the ori region. Cell 28: 767-779.

Herr, W. and J. Clarke. 1986. The SV40 enhancer is composed of multiple functional elements that can compensate for one another. Cell 45: 461-470.

Imagawa, M., R. Chiu, and M. Karin. 1987. Transcription factor AP-2 mediates induction by two different signal-transduction pathways: Protein kinase C and cAMP. Cell 51: 251260.

Israel, A., A. Kimura, M. Kieran, O. Yano, J. Kanellopoulos, O. Le Bail, and P. Kourilsky. 1987. A common positive transacting factor binds to enhancer sequences in the promoters of mouse $\mathrm{H}-2$ and $\beta 2$-microglobulin genes. Proc. Natl. Acad. Sci. 84: 2653-2657.

Johnson, P.F., W.H. Landschultz, B.J. Graves, and S.L. McKnight. 1987. Identification of a rat liver nuclear protein that binds to the enhancer core element of three animal viruses. Genes Dev. 1: 133-146.

Jones, N.C., P.W.J. Rigby, and E.B. Ziff. 1988. Trans-acting protein factors and the regulation of eukaryotic transcription: Lessons from studies on DNA tumor viruses. Genes Dev. 2: $267-281$.

Kadonaga, J.T. and R. Tjian. 1986. Affinity purification of sequence-specific DNA binding proteins. Proc. Natl. Acad. Sci. 83: 5889-5893.

Laemmli, U.K. 1970. Cleavage of structural proteins during the assembly of the head of bacteriophage T4. Nature 227: 680-
685.

Laimins, L.A., G. Khoury, C. Gorman, B. Howard, and P. Gruss. 1982. Host-specific activation of transcription by tandem repeats from simian virus 40 and Moloney murine sarcoma virus. Proc. Nat1. Acad. Sci. 79: 6453-6457.

Lee, W., P. Mitchell, and R. Tjian. 1987. Purified transcription factor AP-1 interacts with TPA-inducible enhancer elements. Cell 49: 741-752.

Maxam, A.M. and W. Gilbert. 1980. Sequencing end labeled DNA with base-specific chemical cleavages. Methods Enzymol. 65: 499-560.

Mitchell, P., C. Wang, and R. Tjian. 1987. Positive and negative regulation of transcription in vitro: Enhancer-binding protein AP-2 is inhibited by SV40 T antigen. Cell 50: 847-861.

Moreau, P., R. Hen, B. Wasylyk, R. Everett, M.P. Gaub, and P. Chambon. 1981. The SV40 72 base pair repeat has a striking effect on gene expression both in SV40 and other chimeric recombinants. Nucleic Acids Res. 9: 6047-6068.

Nomiyama, H., C. Fromental, J.H. Xiao, and P. Chambon. 1987. Cell-specific activity of the constituent elements of the simian virus 40 enhancer. Proc. Natl. Acad. Sci. 84: 78817885.

Oakley, B.R., D.R. Kirsch, and N.R. Morris. 1980. A simplified ultrasensitive silver stain for detecting proteins in polyacrylamide gels. Anal. Biochem. 105: 361-363.

Ogata, R.T. and W. Gilbert. 1977. Contacts between the lac repressor and thymines in the lac operator. Proc. Natl. Acad. Sci. 74: 4973-4976.

Ohlsson, H. and T. Edlund. 1986. Sequence-specific interactions of nuclear factors with the insulin gene enhancer. Cell 45: 35-44.

Ondek, B., A. Shepard, and W. Herr. 1987. Discrete elements within the SV40 enhancer region display different cell-specific enhancer activities. EMBO I. 6: 1017-1025.

Rosenfeld, P.J. and T.J. Kelly. 1986. Purification of nuclear factor I by DNA recognition site affinity chromatography. I. Biol. Chem. 261: 1398-1408.

Schirm, S., J. Jiricny, and W. Schaffner. 1987. The SV40 enhancer can be dissected into multiple segments, each with a different cell type specificity. Genes Dev. 1: 65-74.

Sen, R. and D. Baltimore. 1986a. Multiple nuclear factors interact with the immunoglobulin enhancer sequences. Cell 46: 705-716.

- 1986b. Inducibility of $\mathrm{k}$ immunoglobulin enhancerbinding protein NF-kB by a posttranslational mechanism. Cell 47: 921-928.

Singh, H., J.H. LeBowitz, A.S. Baldwin, Jr., and P.A. Sharp. 1988. Molecular cloning of an enhancer binding protein: Isolation by screening of an expression library with a recognition DNA site. Cell 52: 415-423.

Suck, D., A. Lahm, and C. Oefner. 1988. Structure refined to $2 \AA$ of a nicked DNA octanucleotide complex with DNase I. Nature 332: 464-468.

Treisman, R. 1985. Transient accumulation of c-fos RNA following serum stimulation requires a conserved 5 ' element and c-fos 3' sequences. Cell 42: 889-902.

1987. Identification and purification of a polypeptide that binds to the c-fos serum response element. $E M B O J$. 6: 2711-2717.

Weiher, H., M. Konig, and P. Gruss. 1983. Multiple point mutations affecting the simian virus 40 enhancer. Science 219: 626-631.

Wildeman, A.G., M. Zenke, C. Schatz, M. Wintzerith, T. Grundstrom, H. Matthes, K. Takahashi, and P. Chambon. 1986. Specific protein binding to the simian virus 40 enhancer in vitro. Mol. Cell Biol. 6: 2098-2105. 
Clark et al.

Xiao, J.H., I. Davidson, M. Macchi, R. Rosales, M. Vigneron, A. Staub, and P. Chambon. 1987a. In vitro binding of several cell-specific and ubiquitous nuclear proteins to the GT-1 motif of the SV40 enhancer. Genes Dev. 1: 794-807.

Xiao, J.H., I. Davidson, D. Ferrandon, R. Rosales, M. Vigneron, M. Macchi, F. Ruffenach, and P. Chambon. 1987b. One cellspecific and three ubiquitous nuclear proteins bind in vitro to overlapping motifs in the domain B1 of the SV40 enhancer. EMBO J. 6: 3005-3013.

Yano, O., J. Kanellopoulos, M. Kieran, O. Le Bail, A. Israel, and P. Kourilsky. 1987. Purification of KBFI, a common factor binding to both $\mathrm{H}-2$ and $\beta 2$-microglobulin enhancers. EMBO J. 6: 3317-3324.

Zenke, M., T. Grundstrom, H. Matthes, M. Wintzerith, C. Schatz, A. Wildeman, and P. Chambon. 1986. Multiple sequence motifs are involved in SV40 enhancer function. $E M B O$ I. 5: 387-397.

Zinn, K. and T. Maniatis. 1986. Detection of factors that interact with the human $\beta$-interferon regulatory region in vivo by DNase I footprinting. Cell 45: 611-618. 


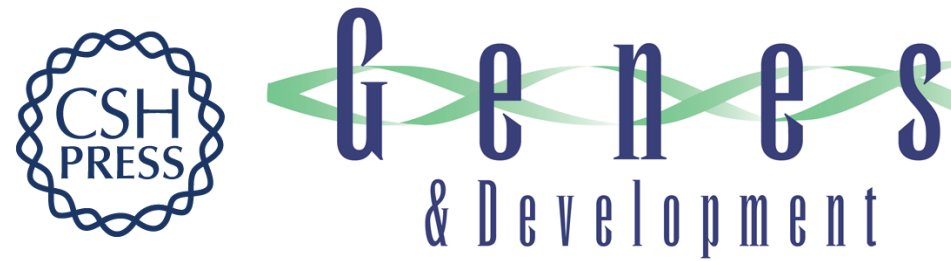

\section{Identification and purification of EBP1: a HeLa cell protein that binds to a region overlapping the 'core' of the SV40 enhancer.}

L Clark, R M Pollock and R T Hay

Genes Dev. 1988, 2:

Access the most recent version at doi:10.1101/gad.2.8.991

References This article cites 51 articles, 15 of which can be accessed free at:

http://genesdev.cshlp.org/content/2/8/991.full.html\#ref-list-1

License

Email Alerting

Service

Receive free email alerts when new articles cite this article - sign up in the box at the top right corner of the article or click here.

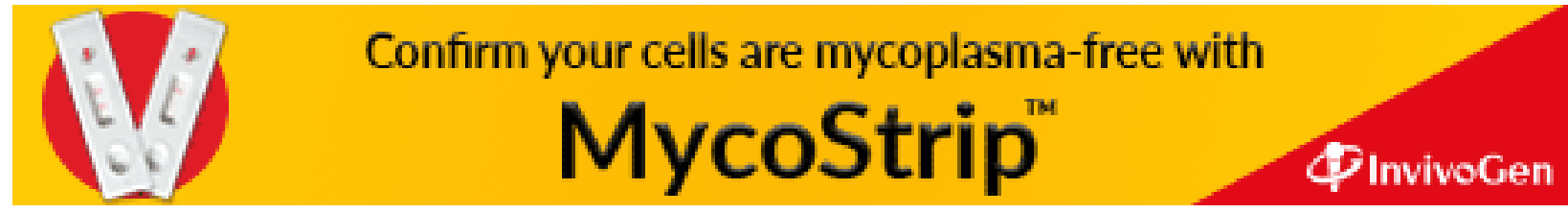

